\begin{tabular}{c} 
International Journal of Scientific World, $5(1)(2017) 74-79$ \\
International Journal of Scientific World \\
SPC \\
Website: $\begin{array}{c}\text { ww. sciencepubco.com/index. } h \text { h } / I J S W \\
\text { doi: } 10.14419 / i j s w . v 5 i 1.7442 \\
\text { Research paper }\end{array}$ \\
\hline
\end{tabular}

\title{
Exposure to uppercott induces hepatotoxicity in male albino wistar rats
}

\author{
Modo, Emmanuel U ${ }^{1 *}$, Uboh, Friday E ${ }^{2}$; Agiang, Margaret A ${ }^{\text {; }}$ Ewere Efosa G. ${ }^{3}$ \\ ${ }^{1}$ Department of Biochemistry, Faculty of Science, Madonna University, Nigeria. Elele campus. Rivers State, Nigeria \\ ${ }^{2}$ Department of Biochemistry, Faculty of Basic Medical Sciences, University of Calabar, Calabar, Cross River State, Nigeria \\ ${ }^{3}$ Department of Biochemistry, Faculty of Basic Medical Sciences, University of Uyo, Uyo, Akwa Ibom State, Nigeria
}

*Corresponding author E-mail: emmanuelmodo@yahoo.com

\begin{abstract}
Background: The use of herbicides and pesticides in agriculture and for public health purposes has led to harmful effects in many nontarget species including man.

Methods: In this study, the hepatic effect of exposure to cypermethrin and dimethoate mixture (uppercott) was investigated in male albino wistar rats. Forty five (45) male wistar albino rats were distributed into five (5) groups of nine (9) animals each. Groups 1 and 2 served as the normal control and oil control respectively, groups 3, 4 and 5 received $2.5 \%, 5 \%$ and $7.5 \%$ LD 50 of uppercott orally for 28 days.

Results: Results obtained revealed that uppercott exposure significantly $(\mathrm{p}<0.05)$ increased serum aspartate aminotransferase (AST) activity, alanine aminotransferase (ALT) activity and alkaline phosphatase (ALP) activity when the test groups were compared with control. Also, uppercott exposure raised serum bilirubin concentration slightly insignificantly compared to the control. Superoxide dismutase activity was significantly reduced across all test groups as compared with compared with control. Histology of liver tissues revealed patchy necrotic sessions in the liver tissues of the test experimental groups $(2.5 \%, 5 \%$ and $7.5 \%)$.

Conclusion: The results obtained from this study are strongly indicative of the hepatotoxic effect of uppercott pesticide and hence, caution during usage is advised.
\end{abstract}

Keywords: Alanine Transaminase (ALT); Alkaline Phosphatase (ALP); Aspartate Transaminase (AST); Hepatotoxicity; Uppercott Pesticide.

\section{Introduction}

Pesticides are substances meant for attracting, seducing, destroying, or mitigating any pest [1]. They are either chemical or biological agents which slow, weaken, or deter pests. Those targeted are insects, weeds, plant pathogens, mollusks, mammals, fish, birds, microbes, and nematodes. The enormous beneficial uses of pesticides notwithstanding, pesticides could be potentially toxic to man and other desired species. Pesticides are most commonly used as plant protection products, which generally guide against attacks from weeds, plant diseases or insects. Pesticides encompass insecticides, herbicides, termiticide, molluscicide, piscicide, avicide, fungicide, disinfectant, and sanitizer to mention but a few [2]. Pesticides have been shown to help in the prevention of sickness in man which possibly is food related, like food infected with molds or infected produce. Uppercott is a type of pesticide composed of two main components namely cypermethrin $(30 \mathrm{~g} / \mathrm{l})$ and dimethoate $(250 \mathrm{~g} / \mathrm{l})$.

The liver is an organ situated in the upper and right part of the abdominal cavity, below the diaphragm. It is the largest organ in the body weighing between $3 \%$ and $4 \%$ of the total body weight. It has four lobes consisting of 50,000 to 100,000 individual hepatic lobules [3]. According to [4], the liver, the largest organ in the body, is often the target organ for chemically induced injuries. There are a number of reasons why the liver is particularly susceptible. Firstly, it is not surprising that the liver is the first point of call when xenobiotics are involved. This is because, most xenobi- otics actually get into the body using the gastrointestinal (GI) tract and, once completely absorbed; they are moved to the liver through the help of the hepatic portal vein. Secondly, as mentioned earlier, the liver has a very high concentration of the enzymes responsible for metabolising xenobiotics, notably the CYP $\mathrm{P} 450$-dependent monooxygenase system. Even though most biotransformations usually happen to be detoxification reactions, the oxidative reactions end up producing highly reactive metabolites capable of inducing liver necrosis. The areas often damaged are mostly in the centrilobular region [5], this is because there is a reasonably higher concentration of cytochrome $\mathrm{P} 450$ in that section of the liver [5]. The liver could be affected by different types of injury ranging from fatty liver, necrosis, apoptosis and cholestasis [6].

Knowing that the liver is the major organ involved in xenobiotic metabolism, this study was therefore carried out to investigate the effect of Uppercott pesticide on liver integrity in Wistar albino rats.

\section{Methods}

\subsection{Chemicals and reagents}

All chemicals and reagents used were of analytical grade. Uppercott pesticide was purchased from Agro chemical company in Calabar, Cross river state, Nigeria. 


\subsection{Experimental animals}

Forty-five (45) male wistar albino rats weighing between 150$180 \mathrm{~g}$ were used for the experiments. They were gotten from the animal grooming section of the department of Biochemistry, University of Calabar and allowed to acclimatize for one week. All animals were maintained under standard conditions and were given normal pellet diet ad libitum.

\subsection{Experimental design and treatment of animals}

Prior to the study, the $\mathrm{LD}_{50}$ of the Uppercott pesticide was determined to be $14.14 \mathrm{mg} / \mathrm{kg}$ body weight adopting Lorke's method [7]. The experimental animals were divided into five (5) groups of nine (9) rats each as shown below:

Table 1: Distribution of Animals into Experimental Groups

\begin{tabular}{lll}
\hline Groups & Number of animals & Treatments \\
\hline Group 1 & 9 males & Control (untreated) $(\mathrm{NCM})$ \\
Group 2 & 9 males & Control administered only oil (OCM) \\
Group 3 & 9 males & $2.5 \%(0.35 \mathrm{mg} / \mathrm{kg} \mathrm{b.wt})$ of $\mathrm{LD}_{50}$ \\
Group 4 & 9 males & $5 \%(0.71 \mathrm{mg} / \mathrm{kg} \mathrm{b} . \mathrm{wt})$ of $\mathrm{LD}_{50}$ \\
Group 5 & 9 males & $7.5 \%(1.06 \mathrm{mg} / \mathrm{kg} \mathrm{b} . \mathrm{wt})$ of $\mathrm{LD}_{50}$ \\
\hline
\end{tabular}

Treatments were by oral administration and lasted for 28days.

\subsection{Collection of blood samples and procedure}

At the end of treatments, 5 rats were selected at random from each group and sacrificed. Blood samples were collected by cardiac puncture into plain screw-cap sample bottles for the liver function tests (LFTs) and antioxidant assay. The blood samples were spun with the aid of MSE model (England) table-top centrifuge at 2000 rpm for 5 minutes. The sera collected were used for biochemical analyses. All biochemical analyses were carried out within 24 hours of serum separation.

\subsubsection{Determination of bilirubin concentration}

Bilirubin was estimated using Span assay kits [8].

(a) Total bilirubin

To $50 \mathrm{ml}$ of sodium nitrite solution $29 \mathrm{mM}, 200 \mathrm{ml}$ sulfanilic acid $(29 \mathrm{mM}$ in $170 \mathrm{mM} \mathrm{HCl}), 1 \mathrm{ml}$ caffeine $(130 \mathrm{mM}$ in $156 \mathrm{mM}$ sodium benzoate and $460 \mathrm{mM}$ sodium acetate), and $200 \mathrm{ml}$ serum added. After mixing, these were allowed to stand at $37^{\circ} \mathrm{C}$ for 10 minute. $1 \mathrm{ml}$ Fehling II $(930 \mathrm{mM}$ potassium sodium tartrate, 1.9 $\mathrm{M}$ sodium hydroxide) solution was mixed with it. A reagent blank was prepared as above without using sodium nitrite. After 5 minutes, absorbance was recorded against blank at $578 \mathrm{~nm}$.

(b) Direct bilirubin

To $50 \mu \mathrm{l}$ sodium nitrite solution, $200 \mu \mathrm{l}$ sulfanilic acid, $2 \mathrm{ml}$ isotonic saline and $200 \mu \mathrm{l}$ of serum was added, mixed well and allowed to stand at $37^{\circ} \mathrm{C}$ for 5 minutes. A reagent blank was prepared as above using sodium nitrite. After 5 min, absorbance was recorded against blank at $546 \mathrm{~nm}$.
2.4.2. Determination of serum aspartate aminotransferase (AST) Activity

AST was assayed using Agappe assay kits [9]. $100 \mu \mathrm{l}$ serum was added to $1 \mathrm{ml}$ of working reagent. The change in absorbance per 20 second during 1 minute was recorded against blank at $340 \mathrm{~nm}$.

\subsubsection{Determination of serum alanine aminotransferase (ALT) Activity}

ALT was assayed using Agappe assay kits [9]. $100 \mu \mathrm{l}$ of serum was added to $1 \mathrm{ml}$ working reagent. After mixing tubes were incubated for 1 minute at $37^{\circ} \mathrm{C}$. The change in absorbance per minute during 3 minute was recorded against blank at $340 \mathrm{~nm}$.

\subsubsection{Determination of serum alkaline phosphatase (ALP)} Activity

Alkaline Phosphatase activity in serum was assayed using Agappe assay kits [10]. $20 \mu \mathrm{l}$ serum was added to $1 \mathrm{ml}$ of working reagent. The tubes were incubated for 1 minute at $37^{\circ} \mathrm{C}$. The change in absorbance per minute during 3 minute was recorded against blank at $405 \mathrm{~nm}$.

\subsubsection{Superoxide dismutase (SOD) activity assay}

The enzyme activity was assayed using Fortress assay kits by measuring the oxidation of NADH [11]. $0.2 \mathrm{ml}$ ethanolchloroform mixture ( $1 \mathrm{ml}$ ethanol and $0.6 \mathrm{ml}$ chloroform) was added to $0.5 \mathrm{ml}$ hemolysate to remove hemoglobin. After shaking, $0.4 \mathrm{ml}$ distilled water was added. It was mixed thoroughly and incubated for 15 minutes and centrifuged. The supernatant was used for determining superoxide dismutase activity. The assay system contained $0.8 \mathrm{ml} 0.1 \mathrm{M}$ triethanolamine-diethanolamine$\mathrm{HCl}$ (TDB) buffer, pH 7.4; $0.04 \mathrm{ml} 7.5 \mathrm{mM}$ NADH, $0.025 \mathrm{ml}$ (100 mM / $50 \mathrm{mM}$ ) EDTA - $\mathrm{MnCl}_{2}, \mathrm{pH} 7.0$ and $0.1 \mathrm{ml}$ sample (or solvent for the control). After thorough mixing, the absorption was recorded at $340 \mathrm{~nm}$, against air for a stable baseline recorded over a 5 minute period. Then $0.1 \mathrm{ml} 10 \mathrm{mM}$ B-mercaptoethanol was added and the final volume in the cuvette was $1.065 \mathrm{ml}$. After mixing, the decrease in the absorbance was monitored for about 20 minutes to allow full expression of the chain length leading to NADH oxidation.

\subsubsection{Statistical analysis}

Data obtained was expressed as Mean \pm Standard Deviation and analyzed using the SPSS package 19.0. One-way Analysis of Variance (ANOVA) was used. Values at $\mathrm{P}<0.05$ were regarded as statistically significant.

\section{Results}

\subsection{Effect of uppercott pesticide on serum liver enzyme activities}

Results obtained revealed that AST, ALT and ALP activities were all significantly $(\mathrm{p}<0.05)$ increased across all test groups compared to the control as seen in figure 1 below. 


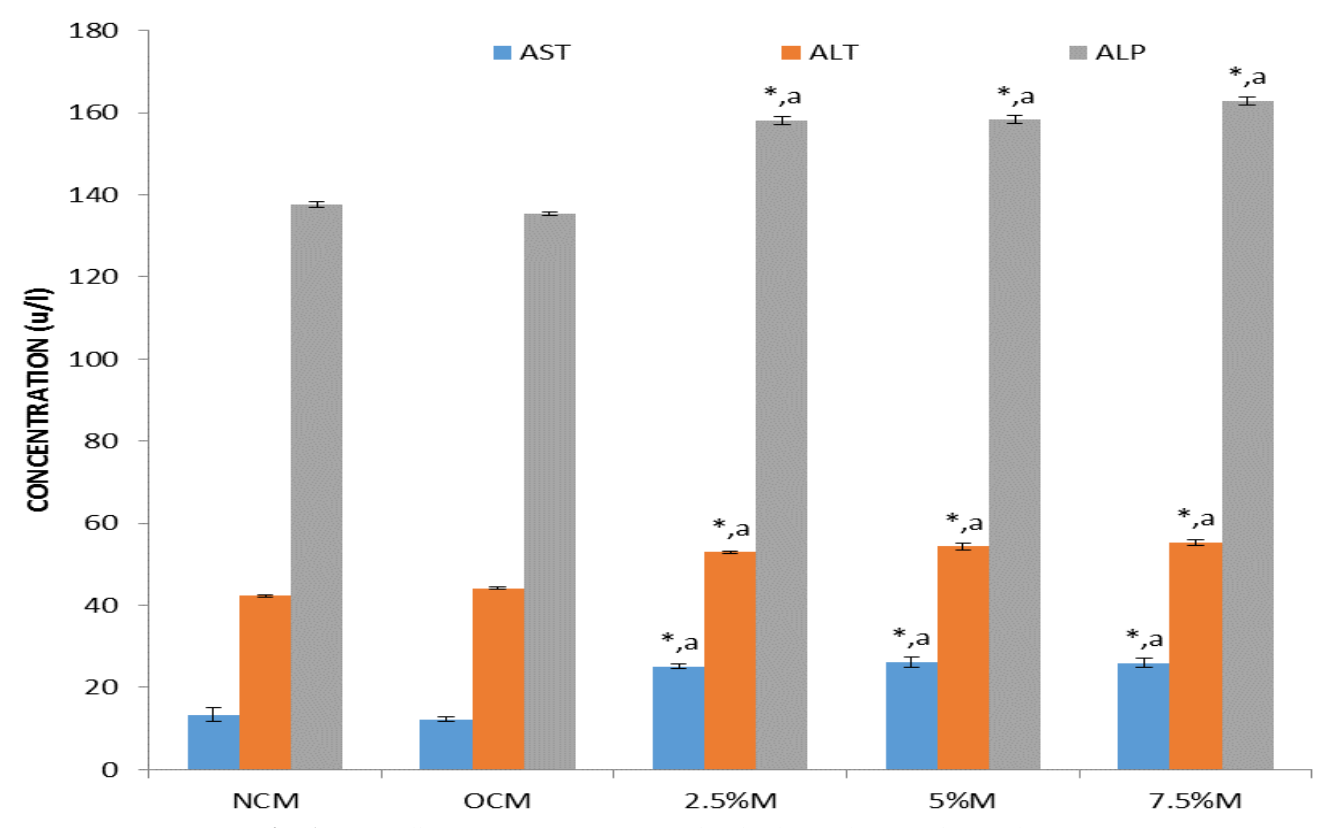

Values are expressed as mean $\pm \mathrm{SD}, \mathrm{n}=5 .{ }^{*}=$ significantly different $(\mathrm{p}<0.05)$ compared with normal control $(\mathrm{NCM}),{ }^{\mathrm{a}=}$ significantly different $(\mathrm{p}<0.05)$ compared with oil control $(\mathrm{OCM})$

\subsection{Effect of uppercott pesticide on serum bilirubin concentrations}

both the total and conjugated bilirubin levels across all test groups compared with the control.

Both total and conjugated bilirubin concentrations are shown in figure 2 below. There was no significant difference observed in

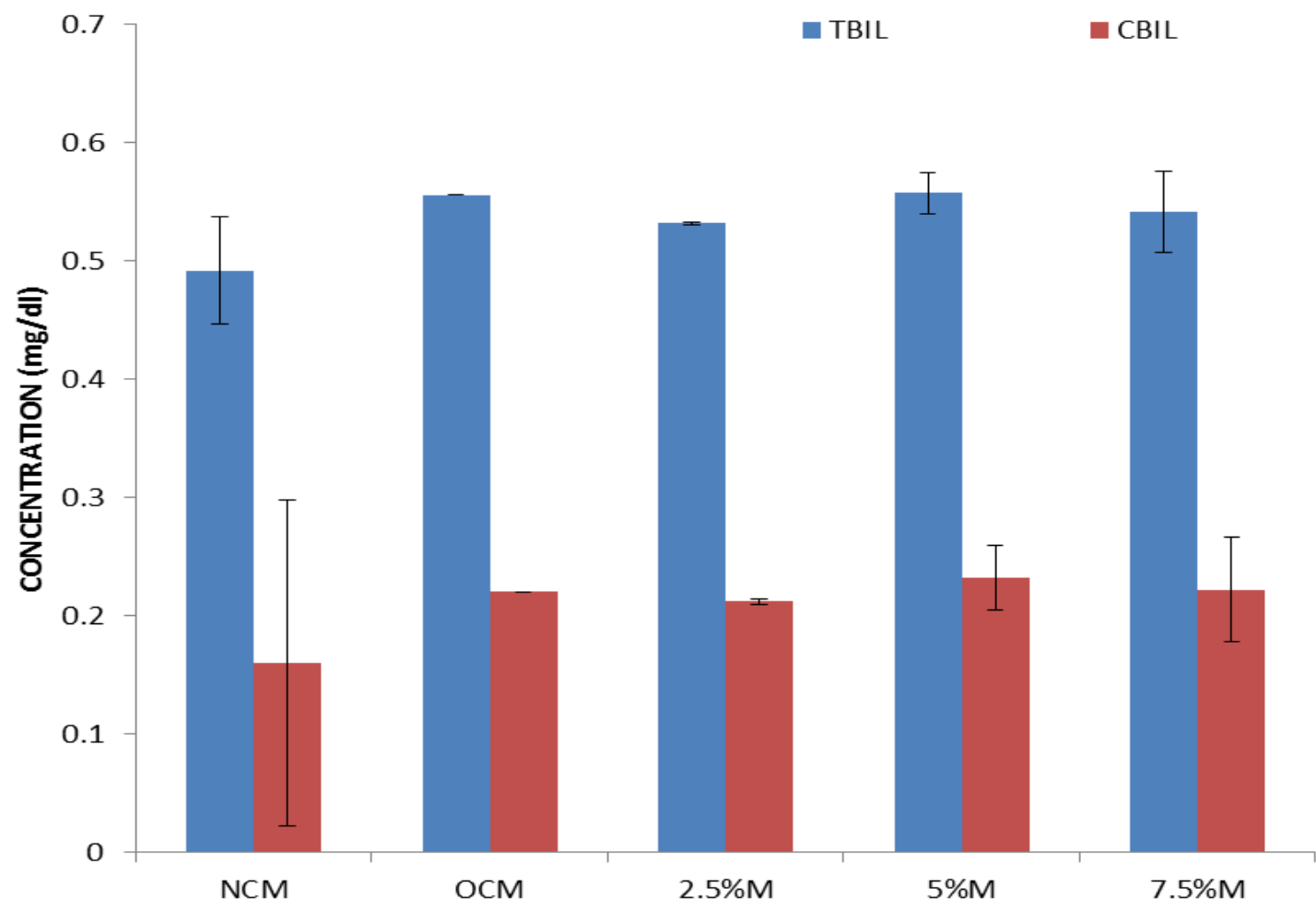

Fig. 2: Bilirubin Concentration the Male Experimental Rats.

Values are expressed as mean $\pm \mathrm{SD}, \mathrm{n}=5 . \mathrm{P}>0.05$

\subsection{Effect of uppercott pesticide on serum superoxide dismutase activity}

As shown in figure 3 below, serum SOD activities were significantly $(\mathrm{p}<0.05)$ decreased when all other groups were compared with the normal control group and when all uppercott treated groups were compared with the oil control in a dose-dependent manner. Also, comparism of groups 4 and 5 (5\% and 7.5\% uppercott) with group 3 ( $2.5 \%$ uppercott) revealed significant $(\mathrm{p}<0.05)$ decreases in SOD activities. 


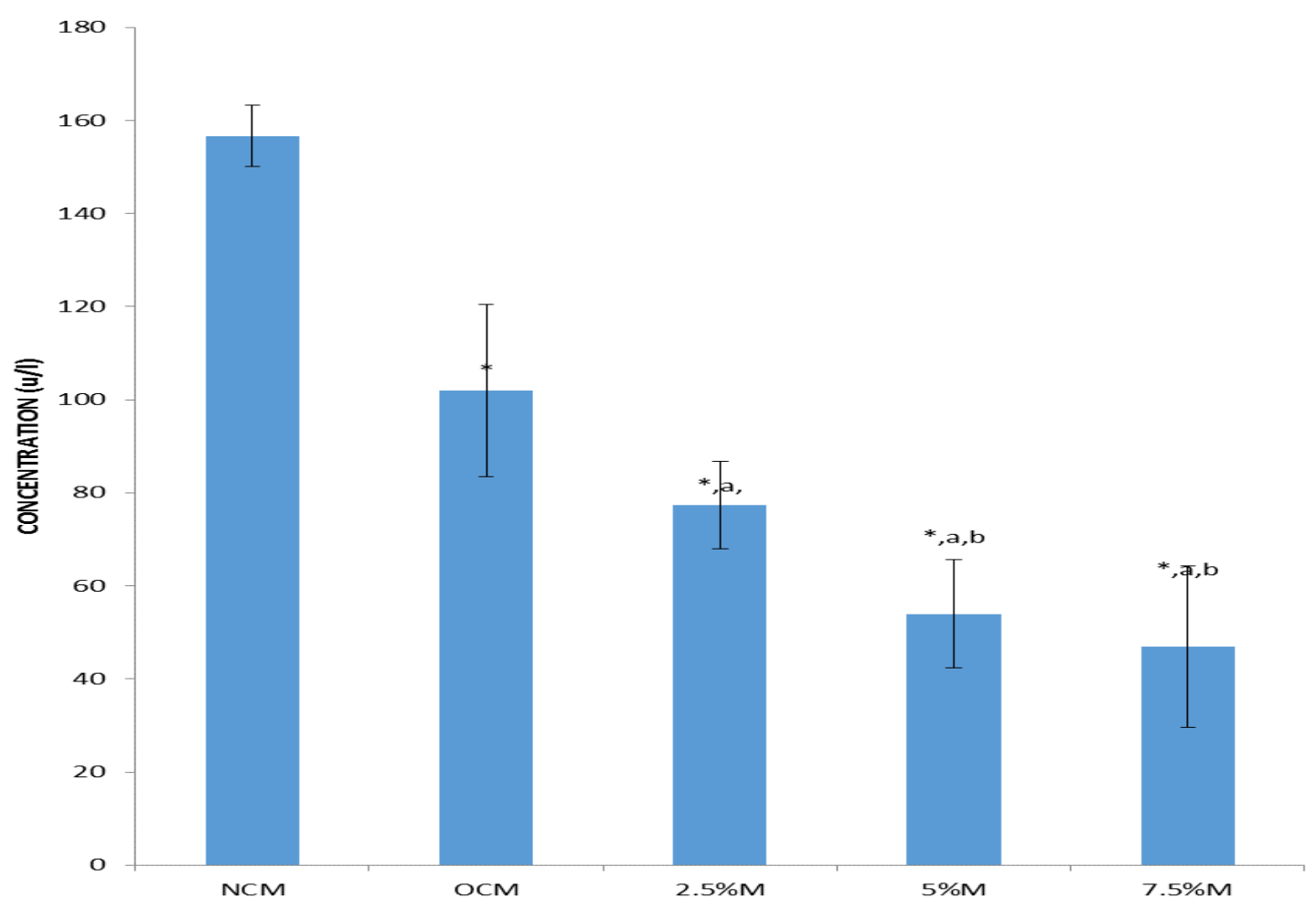

Fig. 3: Superoxide Dismutase Concentration in the Male Experimental Rats.

Values are expressed as mean $\pm \mathrm{SD} ; \mathrm{n}=5 ; *=$ significantly different $(\mathrm{p}<0.05)$ compared with normal control $(\mathrm{NCM})$; ${ }^{\mathrm{a}}=$ significantly different $(\mathrm{p}<0.05)$ compared with oil control $(\mathrm{OCM}){ }^{\mathrm{b}}=$ significantly different $(\mathrm{p}<0.05)$ compared with group 3 ( $2.5 \%$ uppercott $)$.

\subsection{Effect of uppercott pesticide on liver histology}

Plates $1 \mathrm{a}_{1 \mathrm{M}}-1 \mathrm{a}_{5 \mathrm{M}}$ show the histological sections of the liver tissues. There was preserved histo-architecture of the liver cells having central veins and radially displaced hepatocytes in normal control (NCM). The central veins were slightly congested and the sinusoidal spaces were prominent. There were patchy necrotic sessions in the liver tissues of the oil control and other experimental groups (OCM, and $2.5 \%, 5 \%$ and $7.5 \%)$. These were shown in figure 4

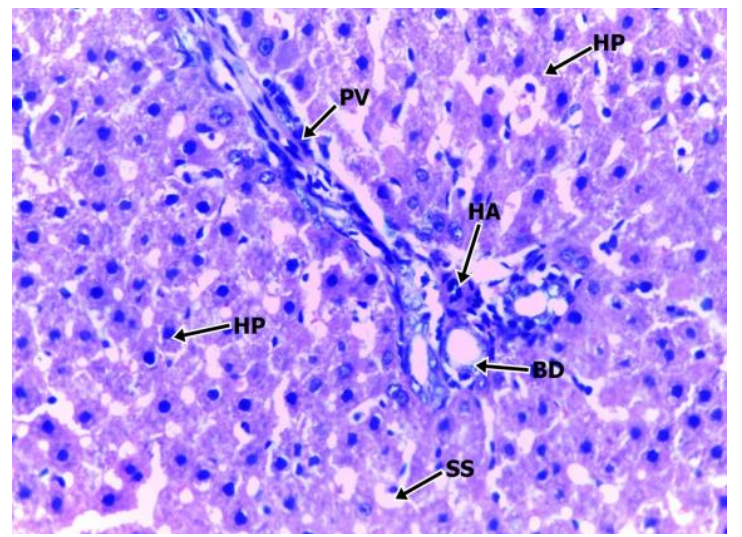

Plate1a2M: Photomicrograph of Oil Control (OCM) Rat Liver. (Mag X 400).

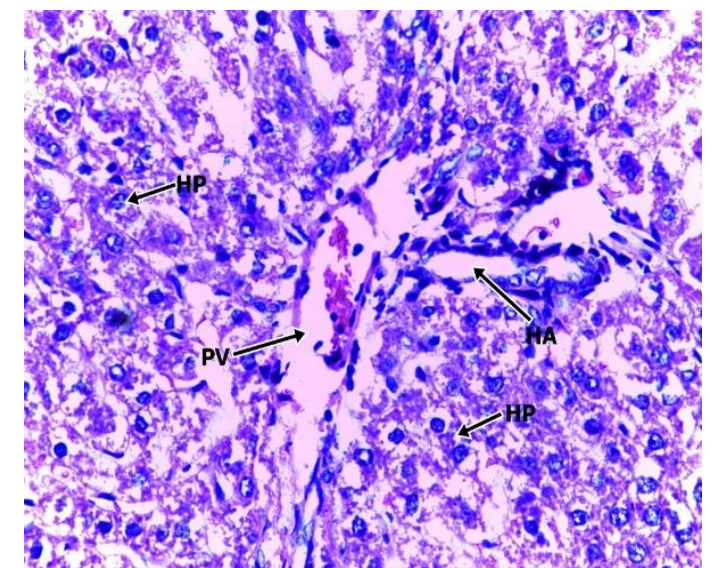

Plate1a1M: Photomicrograph of Normal Control (NC) Rat Liver. (Mag. X 400).



Plate1a3M: Photomicrograph of Rat Liver Exposed To 2.5\% Uppercott Insecticide (Mag. X 400). 


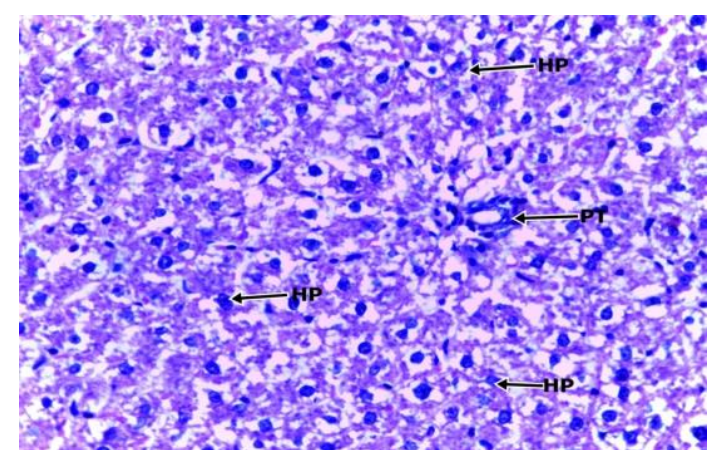

Plate 1a4m: Photomicrograph of Rats Liver Exposed To 5\% Uppercott Insecticide (Mag.X 400),

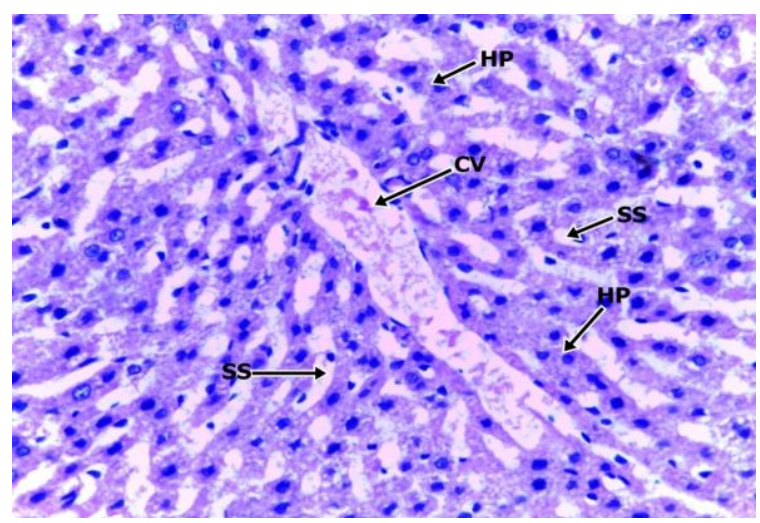

Plate1a5M: Photomicrograph of Rat Liver Exposed To 7.5\% Uppercott Insecticide (Mag. X 400).

HP- hepatocytes, SS- sinusoidal space, CV- central vein, HAhepatic artery

Fig.4: Effect of Uppercott Pesticide on Histology of Liver Tissues in Experimental Rats.

\section{Discussion}

Most orally ingested xenobiotics and drugs are metabolized in the liver into toxic intermediates, making the liver a major target organ for xenobiotic and drug toxicity [12]. Aspartate aminotransferase (AST) and alanine aminotransferase (ALT) are transaminases that catalyse the transfer of amino groups for biochemical purposes. They are majorly found in the liver. Liver injury stemming from its exposure to toxic chemicals leads to elevated levels of these enzymes in the blood. Thus, the degree of liver damage relates directly to the level of AST and ALT in the blood [13] [14] [15]. Alkaline phosphatases (ALP) are enzymes involved in catalyzing the hydrolysis of organic phosphate at alkaline $\mathrm{pH}$. They are very high in concentration in hepatobiliary tract [16]. Serum ALP activity may be elevated due to xenobiotic-induced hepatotoxicity [17].

In the present study, significantly elevated levels of AST, ALT and ALP in the test groups as compared with the control (Fig. 1.) suggests hepatotoxicity of uppercott pesticide leading to the compromise of liver integrity. This is supported by the results of the liver histology in this study. This also corroborates the findings from other studies on the hepatotoxic effects of toxic chemicals in experimental rats [18][19]. It was also observed that there was an insignificant rise in the levels of bilirubin in the test animals as compared with the controls. This might be attributed to prolonged exposure to pesticides which interrupted the normal red blood cell metabolism, affecting the hepatic dysfunction and increased the level of bilirubin in the blood thereby causing hyperbilirubinemia which might be due to production of excess bilirubin than the normal liver can excrete [20] [21] [22].
Most toxic chemicals are known to generate free radicals and other reactive oxygen species as a way of eliciting their toxicities. Superoxide dismutase (SOD) is an enzyme that inhibits the action of superoxide free radical which can cause oxidative stress. It catalyses the dismutation of superoxide radical to hydrogen peroxide which is then eliminated by another endogenous enzyme, catalase [23]. SOD can therefore function in primary defense and inhibits further production of free radicals. In the present study, exposure of experimental rats to different doses of uppercott pesticide resulted in significant decreases in SOD activities compared with the control (Fig. 3). This may be due to induction of oxidative stress by the pesticide since there is perturbation of antioxidant/oxidant biological status in favour of oxidant status in oxidative stress.

\section{Conclusion}

The present study revealed that Cypermethrin and dimethoate mixture (uppercott) exposure is a potential threat to normal functioning of the liver. Uppercott pesticide is therefore a potential health threat and hence, a need for caution in the agricultural and household usage of this chemical is greatly advised.

\section{References}

[1] United States Environmental Protection Agency. What is a pesticide? http://www.epa.gov/pesticides 2007. Accessed November 18, 2014.

[2] R. Carolyn, H. Winand, C. Edward, H. Colleen, National Pesticide Applicator Certification Core Manual. National Association of State Departments of Agriculture Research Foundation, Washington, DC 2013.

[3] R.K Stoelting, Liver and digestive tract. In R. K. Stoelting (Ed.), Pharmacology and physiology in anesthetic practice. 2nd edition. Philadelphia, J. B. Lippicott. 1991; 2: 782 - 794.

[4] E. Hodgson, S.A. Meyer, Pesticides In: Hepatic and Gastrointestinal Toxicology, Permagon/Elsevier, Comprehensive Toxicology (1997) 9: 369-387.

[5] M. Treinen-Moslen, Toxic responses of the liver. In Casarett and Doull's Toxicology: The Basic Science of Poisons, Klassen, C., Ed., McGraw-Hill, New York, 2001; 471-489.

[6] S.A. Meyer, Overview of hepatotoxicity in: current protocols in toxicology (Maines, M.D., ed), John Wiley \& Sons, New York 2001. https://doi.org/10.1002/0471140856.tx1401s08.

[7] D. Lorke, A new approach to practical acute toxicity testing. Ar$\begin{array}{lllll}\text { chive of Toxicology (1983) } 54 & \text { (4):275-87. }\end{array}$ https://doi.org/10.1007/BF01234480.

[8] L. Jendrassik, P. Grof, Colorimetric method of determination of bilirubin. Biochem. Z (1938) 297:81-82.

[9] W. Thefeld, H. Hoffmeister, E.W. Busch, P.U. Koller, J. Vollmar, Reference values for the determination of GOT, GPT and alkaliphosphatase in serum with optimal standard methods. Dtsch Med. W ochenschr. (1974) 99:343 - 351. https://doi.org/10.1055/s0028-1107760.

[10] H. Schlebusch, W. Rick, H. Lang, M. Knedal, Standards in the activities of clinically important enzymes. Dtsch Med Inochenschr, (1974) 99, 765 - 766. https://doi.org/10.1055/s-0028-1107840.

[11] F. Paoletti, D. Aldinucci, A. Mocali, A. Caparrini, A sensitive spectrophotometric method for the determination of superoxide dismutase activity in tissue extracts. Analytical Biochemistry (1986) 154: 538-541. https://doi.org/10.1016/0003-2697(86)90026-6.

[12] H. Jaeschke, G.J. Gores, A.I. Cederbaum, J.A Hinson, D. Pessayre, J.J. Lemasters, Mechanisms of hepatotoxicity. Toxicological Sciences (2002) 65:166-176. https://doi.org/10.1093/toxsci/65.2.166.

[13] G. Lum, S.R. Gambino, Serum gamma glutamyltranspepti-dase activity as an indicator of disease of liver, pancreas, or bone. Clinical Chemistry (1972) 18(4):358-362.

[14] A. Halim, O. El-Almady, S. Hassab-Allah, F. Abdel-Gelil, Y. Hafez, A. Derivis, Biochemical effect of antioxidants on lipids and liver function in experimentally induced liver damage. Annals of Clinical Biochemistry (1997) 34:656-663. https://doi.org/10.1177/000456329703400610.

[15] E.O. Udosen, A.S. Ojong, Hepatotoxic activity of Sacoglothis gabonensis in rats. Pharmaceutical Biology (1998) 36(5):467-469. https://doi.org/10.1076/phbi.36.5.368.4648. 
[16] M.A. Crook, Clinical chemistry and metabolic medicine (7th ed.) New Delhi: Edward Arnold 2006.

[17] O. Bodansky, Enzymes in cancer: The phosphohydrolases. In: Biochemistry of human cancer. Bodansky O. (Ed.), New York: Academic Press. 1995; 61-92.

[18] F.E. Uboh, M.I. Akpanabiatu, U.E. Eyong, P.E. Ebong, O.O. Eka, Evaluation of toxicological implications of inhalation exposure to kerosene fumes and petrol fumes in rats. Acta Biologica Szegediensis (2005) 49 (3-4):19-22

[19] E.G. Ewere, S.A. Oyebadejo, V.C. Peter, Ethanolic Leaf Extract of Irvingia gabonensis (O' Rorke) Baill Protects against Nephrotoxicity and Hepatotoxocity in Cadmium-induced Wistar Albino Rats. International Journal of Pharmacology and Toxicology (2016) 4(2): 105-110. https://doi.org/10.14419/ijpt.v4i2.6186.

[20] M. Fahimul-Haq, S. Mahmood, N. Choudhry, T. Shabaz, S. Akram, R. Yasmin, Study of effect of pesticides on total bilirubin and direct bilirubin levels in blood of workers of pesticide formulation \& packing plants in Pakistan: Multiplexing with ALP, ALT and AST. Pakistan Journal of Medical and Health Sciences (2013) 7(3):736739.

[21] M.L. Queiroz, C. Binovoletto, R.C. Perlingeriro, M.R. Quadros, Immunoglobin levels in workers exposed to hexa-chlorobenzene. Human Experimental Toxicology (1998) 17 (3): 172-75. https://doi.org/10.1191/096032798678908477.

[22] E.J. Brower, C.T. Evelo, A.J. Verplanke, R.T. Van Welie, F.A. De Wolff, Biological effect monitoring of occupational exposure to 1,3-dichloropropane: effect on liver and renal function and on glutathione conjugation. British Journal of Industrial Medicine (1991) 48(9): 646-648.

[23] I.F. Usoh, E.J. Akpan, E.O. Etim, E.O. Farombi, Antioxidant actions of dried flower extracts of Hibiscus sabdariffa L. on sodium arsenite-induced oxidative stress in rats. Pakistani Journal of Nutrition (2005) 4: 135-141. https://doi.org/10.3923/pjn.2005.135.141. 